\title{
Review of Revolutionary Parks: Conservation, Social Justice, and Mexico's National Parks, 1910-1940.
}

\author{
ALEJANDRO VELÁZQUEZ \\ Universidad Nacional Autónoma de México, Mexico \\ Revolutionary Parks: Conservation, Social Justice, and Mexico's National \\ Parks, 1910-1940. \\ Written by Emily Wakild, Tucson, US: University of Arizona Press, 2011, \\ ISBN 978-0-8165-2957-5
}

Parks represent a remarkable cultural construct targeted towards maintaining functional ecological integrity and biodiversity regardless of the cost and consequence. In Revolutionary Parks: Conservation, Social Justice, and Mexico's National Parks, Emily Wakild tackles the subject of national parks as a cultural construct by initially reviewing how the original perception of parks evolved directly from a science-oriented understanding of nature. In contrast to this understanding of nature, Native rural communities have regarded national parks as overbearing, colonial symbols of wealth and, therefore, have contested their creation vociferously. In her latest book, Wakild defies the understanding of parks as icons of sound conservation, citing as examples the establishment of Yosemite (1864) and Yellowstone (1872) National Parks. She advances some arguments to demonstrate that other cultural perceptions about parks have evolved and matured as well. One of them was the notion of revolutionary parks, here understood as communal property lands devoted to strengthening the cultural identity of rural stakeholders who fought in the Mexican Revolution.

With a thorough review of the historical literature on parks at the time, the author documents that by 1940 Mexico had established more national parks 
than any other country. Yet, how could a nation emerging from a devastating revolution afford to do so? According to Wakild, Mexican president, Lázaro Cárdenas del Rio, promoted an understanding of parks as symbols of pride and established the largest number of them in a short period of time in a somehow troublesome, poorly developed rural environment.

The book focuses on the administration (1934-1940) of Lázaro Cárdenas del Río, who expressed his willingness and devotion to the principles of revolution and advanced a vision. Wakild shows that Cárdenas regarded parks as environmental stakes, symbols of national pride, and icons of identity. Moreover, he saw parks as tools to be used to promote landowner (latifundistas) dispossession, thereby legitimizing the empowerment of rural people (pueblo).

The establishment of the first parks in Mexico was legally based on the Expropriation of Land for Public Interest Act within the land reform law of 1917 (article 27). However, as new parks were established, land tenure conflicts emerged and the original decree of land expropriation was contested. Without changing the law, Cárdenas recommended that the establishment of parks should guarantee communal land tenure. Thus, "ejidos" (communal lands) recently empowered by the revolution would maintain land rights, but land use within park boundaries would adhere to principles of sustainable conservation (understood as suitable and durable land use practices with low impact on pristine conditions). The expropriation act was meant to be used under extreme circumstances, i.e. when non-conservation land use affected public interests. Consequently, the establishment of Mexican parks represented a strategy employed to avoid disputes between communities and to preclude international claims. This is illustrated by the establishment of Suchiate River Park in Chiapas, which was regarded as a corridor of peace between the governments of Guatemala and Mexico. This initiative was further developed into Transboundary Protected Areas or Peace Parks (www. peaceparks.org) and implemented largely in Africa, Asia, and Latin America.

The author takes readers through remarkable moments that occurred during the establishment and management of four national parks: Izta-Popo (1935), Zempoala (1936), Tepozteco (1937), and Malinche (1938). Izta-Popo was envisioned as an engine for development, given its capacity to provide water, energy, and wood. Nowadays, according to Daily and Matson (2008), ${ }^{1}$ these types of benefits are regarded as ecosystem services. At Izta-Popo, the term "conservation" was understood as the challenge to maintain productive landscapes where nature and culture intermingle. Zempoala, in turn, was launched as an experiment to enhance environmental awareness, promoting the idea of kindergartens as educative terrains for children just as parks were educative terrains for adults. This was the genesis of the numerous centres of environmental education which now exist and which developed out of ecotourism. ${ }^{2}$ The establishment of Tepozteco was first regarded as an impulsive measure, yet this park eventually became a model of communal property stewardship, whereby areas comprising rich archeological, colonial, cultural, and natural elements were to become common national patrimony. Lastly, 
Malinche was the first national park to challenge the idea of expropriation (an understanding mainly espoused by urban and private social sectors) versus appropriation (for and by local social groups).

The book's concluding section contrasts the prevailing understanding of national parks with the concept developed in Mexico. In Mexico, during the 1940 s, parks were established to achieve social dignity, maintain national landscapes, and serve as symbols of sovereignty, patrimony, and inheritance for future generations. The vision of the emerging modern Mexican state was to ensure the long- term coexistence of nature and culture that would recognize both emerging as well as customary use systems as strategies for governance.

Not all experiences in park creation in Mexico were without problems. In fact, the innovative understanding that led to the construction of revolutionary parks was abandoned after Cárdenas left office in 1940. Over the next several decades, disagreements prevailed among those foresters who regarded the creation of parks as a means to conserve temperate ecosystems and those who favoured the introduction of exotic species (eucalyptus and casuarinas, for example). These disagreements took place amid ongoing urban-rural confrontations. Ecological-oriented attitudes were in vogue for many years, attitudes which put biodiversity conservation at the top of the Mexican political agenda and disregarded the socio-cultural nature of Mexico. Unfortunately, these historical and relevant facts related to park establishment are not covered in this book.

Nevertheless, the book does provoke a deep reflection on what it means to be Mexican, a Mexican politician, and a Mexican conservationist. It invites readers to reconsider the concept of sustainability, ecosystem services, ${ }^{3}$ conservation, and parks. Furthermore, the vision described by the author turns out to be quite relevant in the $21^{\text {st }}$ century in light of the world's most urgent needs to implement actions without delay where both nature and culture should be maintained and nourished to ensure human survival.

The lessons learned from the Mexican park experience are relevant to a worldwide audience. Leading conservationist nations, with their belief that there is only one way to perceive and understand parks, would do well to pay attention to this book and to Mexico's long experience in this domain.

\section{Notes}

1 Daily, Gretchen C.; Matson, Pamela A. 2008. Ecosystem services: From theory to implementation. Proceedings of the national academy of sciences of the United States of America, Volume: 105, Issue: 28 Pages: 9455-9456.

2 A term coined later in Mexico by H. Ceballos-Lascurain (Ecotourism as a Worldwide Phenomenon. 1993. In Ecotourism: A Guide for Planners and Managers; K. Lindberg, D. Hawkins, Eds. Ecotourism Society, Alexandria, Va, USA: 1-3).

3 Ecosystem services defined by Daily and Matson (2008) as natural capital assets that provide live-support services of tremendous values. 